\title{
Construct validity of critical thinking disposition test in biology
}

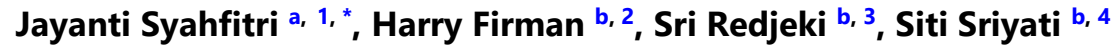 \\ a Biology Education Department, Faculty of Teacher Training and Education, Universitas \\ Muhammadiyah Bengkulu, Indonesia \\ ${ }^{\mathrm{b}}$ Science Education Department, Post Graduate, Universitas Pendidikan Indonesia, Indonesia \\ ${ }^{1}$ jayanti_syahfitri@yahoo.co.id *,2 harry_firman@upi.edu, ${ }^{3}$ sri.redjeki.n@gmail.com, ${ }^{4}$ sriyati@upi.edu \\ * Corresponding author
}

\begin{tabular}{|c|c|}
\hline \multicolumn{2}{|c|}{ ARTICLE INFO } \\
\hline \multicolumn{2}{|c|}{ Article history } \\
\hline Received & August 30, 2018 \\
\hline Revised & December 26,201 \\
\hline Accepted & January 13,2020 \\
\hline \multicolumn{2}{|c|}{ Keyword: } \\
\hline \multicolumn{2}{|c|}{ Construct } \\
\hline \multicolumn{2}{|c|}{$\begin{array}{l}\text { Critical Thinking Disposition } \\
\text { Validity }\end{array}$} \\
\hline
\end{tabular}

\section{Introduction}

Nowadays, critical thinking has been accepted as fundamental component in every education system (Hongladarom, 2007). Currently, skill in critical thinking is very important in facing the world changes. Most purpose of the college is to prepare the students to think critically (Foluso, 2014). This is in line with Bok (2009) statement who explained that critical thinking is one of the focuses that has been developed in education and considered as one of the ways to answer the global challenges faced right now. The fact is critical thinking has been agreed to be the main purpose in academics, especially in college education. Nieto and Valenzuela (2012) added that execution or application of critical thinking is depended on a set of skill and disposition. It is explained indirectly that the skill is not only described by cognitive component, but also disposition. This is supported by Facione (1990) statement that besides the skill as general component, critical thinking also includes specific component which called as disposition.

Critical thinking disposition is really needed to think critically and develop 
critical thinking skill. Disposition in thought has been described as a strong internal tendencies to solve problems and decision making achieved by thinking (Foluso, 2014; Foluso \& Caserina, 2014). In the other word, it is important to know disposition first before developing critical thinking skill, where it is mentioned that critical thinking disposition is initial requirement that is needed to have critical thinking ability (Facione, 2000). Refer to the theory developed by Facione, Giancarlo, Facione, and Gainen (1995), critical thinking disposition consists of seven, namely: Truth Seeking (TS), Open Mind (OM), Analicity (AN), Sistematicity (SIS), Self-Confidence (SC), Inquisitiveness (IN) dan Maturity (MA).

Syahfitri, Firman, Redjeki, and Sriyati (2019) reveals that research related with critical thinking disposition has been developed both in the country or overseas using measurement instrument of critical thinking disposition which is general in nature and using inventory measurement type. As the fact, there has not been any research on critical thinking disposition yet, which focus on biology education, moreover its measurement is related with biology content. Biology learning covers wide concept, so the students are required to have strong critical thinking disposition as their preparation to develop critical thinking skill. Therefore, this research result offers alternative test to see the extent of critical thinking disposition in biology education students. Some reasons of critical thinking disposition test developed were considered more capable in interpreting someone's disposition. With test model in which the questions were related with biology content (which related with aspect/lesson in ecology, structure and function, biotechnology and evolution), it is expected to be able to be objective in interpreting the extent of the student's tendencies. Moreover, critical thinking disposition measurement with inventory was regarded susceptible with fake response. This matter is supported with Widhiarso $(2010,2011)$ and Marcus (2009) statement who explained that measurement in inventory scale is susceptible of manipulation and fake response. And the fact is, by the existence of pretense response, it will weaken the validity of the measuring instrument used (Furnham, 1986; Nederhof, 1985).
The research is one of the steps in developing Critical Thinking Disposition Test in Biology (CTDTB) as alternative instrument that can be used to find or to measure student's critical thinking disposition. As a good instrument requirement, it must have validity value (validity content and construct), and good reliability. This study aims to see how well the construct validity of each item on the Critical Thinking Disposition Test developed in Biology (CTDTB).

\section{Method}

The method of the research was using development and validation method (development and validation) which was confirmed by Confirmatory Factor Analysis. In this research there were three analysis procedures (convergent validity) in finding the construct validity, namely: Factor Loading, Composite Reliability (CR), and Average Variance Extract (AVE) (Fornell \& Larcker, 1981; J Syahfitri, Firman, Redjeki, \& Sriyati, 2019). Factor loading was used to analyze the relation of a construct with its indicator. Standard value (accepted value) of loading factor is more than 0.5 and above. Composite reliability was used to test reliability with criteria value, which is more than 0.7 and above. Average Variance was confirmatory test by finding average value (AVE) among indicators with latent variable. The third method used numbers and correlation between constructs with its indicator, and AVE value is above 0.5 can be said as accepted (Hair, 2011). This research was applied in State University of Bengkulu by involving 206 students of biology education as the respondents which were students of the 1, 2, 3, and 4th year level of study.

Critical thinking disposition test covered 10 item groups or question clusters that consist of 7 multiple choice questions which leads to critical thinking disposition. Every critical thinking disposition indicator were represented by 10 questions, hence, there were total of 70 questions. The test used in this research was validated by group of lecturers who were experts in education (biology content) and also selected based on their experiences in conducting research, those are as much as 6 validators. Form of the questions in critical thinking disposition test was presented in the cases related with 
biological content, each case was developed from four main groups from the biological aspects. The aspects were ecology, structure and function, biotechnology and evolution. Data analysis in the research was carried out using SPSS version 20 Software and AMOS version 20 Application using Confirmatory Factor Analysis (CFA) procedure to confirm construct validity on critical thinking disposition test.

\section{Results and Discussion}

After the critical thinking disposition test was declared valid in content by experts with the results showed that all questions developed had a Content Validation Ratio (CVR) of more than 0.64, as a minimum CVR acceptance value, the next step was looking at the construct validity. Ghadi, Alwi, Bakar, and Talib (2012) construct validity is validity that emphasizes on logical analysis tested correlation based on existing theory. Based on the results of the analysis with Confirmatory Factor Analysis (CFA), it was obtained the interpretation result on feasibility test model and Convergent Validity (Factor Loading, Average Variance Extract, dan Composite Reliability). Later, on Widarjono (2015) revealed that feasibility test model is an initial step in interpreting construct validity, which there are some criteria in determining feasibility test model in critical thinking disposition. The several indexes of the eligibility criteria of the model are looking at scores in Chi-Squares test, Goodness of Fit Index (GFI), Adjusted Goodness of Fit Index (AGFI), Tucker Lewis Index (TLI), Comparative Fix Index (CFI) and Root Mean Squares Residual (RMSR). Feasibility test model in this research can be seen in Table 1 .

On the Table 1, it is shown that critical thinking disposition model, with total respondent data of 206 biology education students which were tested on State University of Bengkulu, was stated as feasible. This is supported with feasible test criteria scores that passed the requirement score of $\mathrm{X} 2 / \mathrm{df}$ is 1.922 . Besides that, after critical thinking disposition test was confirmed using Confirmatory Factor Analysis (CFA), it was obtained scores for the other criteria, which are: GFI=0.609 (approaching to 1), RMSEA $=0.067$ RMR $=0.012$, PNFI $=0.742$ (approaching to 1 ), TLI $=0.870$, and CFI= 0.875 . Based on scores of feasibility test criteria as presented in Table 1, it is known that there are some factors that cannot meet the criteria (CFI, TLI, and GFI), nevertheless, as what Widarjono (2015) said that from the several criteria of the feasibility test on the model, the model can be said to be feasible if it meets one of these methods.

Table 1. Feasibility index of critical thinking disposition test model

\begin{tabular}{lcc}
\hline $\begin{array}{c}\text { Fit } \\
\text { Index }\end{array}$ & $\begin{array}{c}\text { Recommended } \\
\text { Value (Hair, } \\
\text { 2011) }\end{array}$ & $\begin{array}{c}\text { Critical Thinking } \\
\text { Disposition } \\
\text { Model }\end{array}$ \\
\hline$X^{2} / \mathrm{df}$ & $\leq 3$ & 1.922 \\
RMSEA & $\leq 0.08$ & 0.067 \\
GFI & $\geq 0.9$ & $\mathbf{0 . 6 0 9}$ \\
RMR & $<0.5$ & 0.012 \\
TLI & $\geq 0.9$ & 0.870 \\
CFI & $\geq 0.9$ & 0.875 \\
PNFI & $\begin{array}{c}\text { The higher, the } \\
\text { better }\end{array}$ \\
\hline
\end{tabular}

However, it will be better if the model has more than one feasibility method (criteria). Besides, scores of Goodness of Fit Index (GFI), Comparative Fit Index (CFI) and Tucker Lewis Index (TLI) are still approaching number 1 . Therefore, it can be concluded that critical thinking disposition test is feasible to use.

Later on in Figure 1, it can be seen based on CFA test result (after eliminating indicator using low factor loading) shows that the value, in the 10 item groups (questions) for the seven indicators of critical thinking disposition, is said to be acceptable that has a standardized factor loading value as greater than 0.5. Further on Figure 1, it also explains critical thinking disposition test model confirmation which is completed with standardized factor loading for each of the questions on the seven critical thinking disposition indicators. The next step in Convergent Validity test, it must be checked first in the Average Variance Extract (AVE) and Composite Reliability (CR) which can be seen on Table 2. 


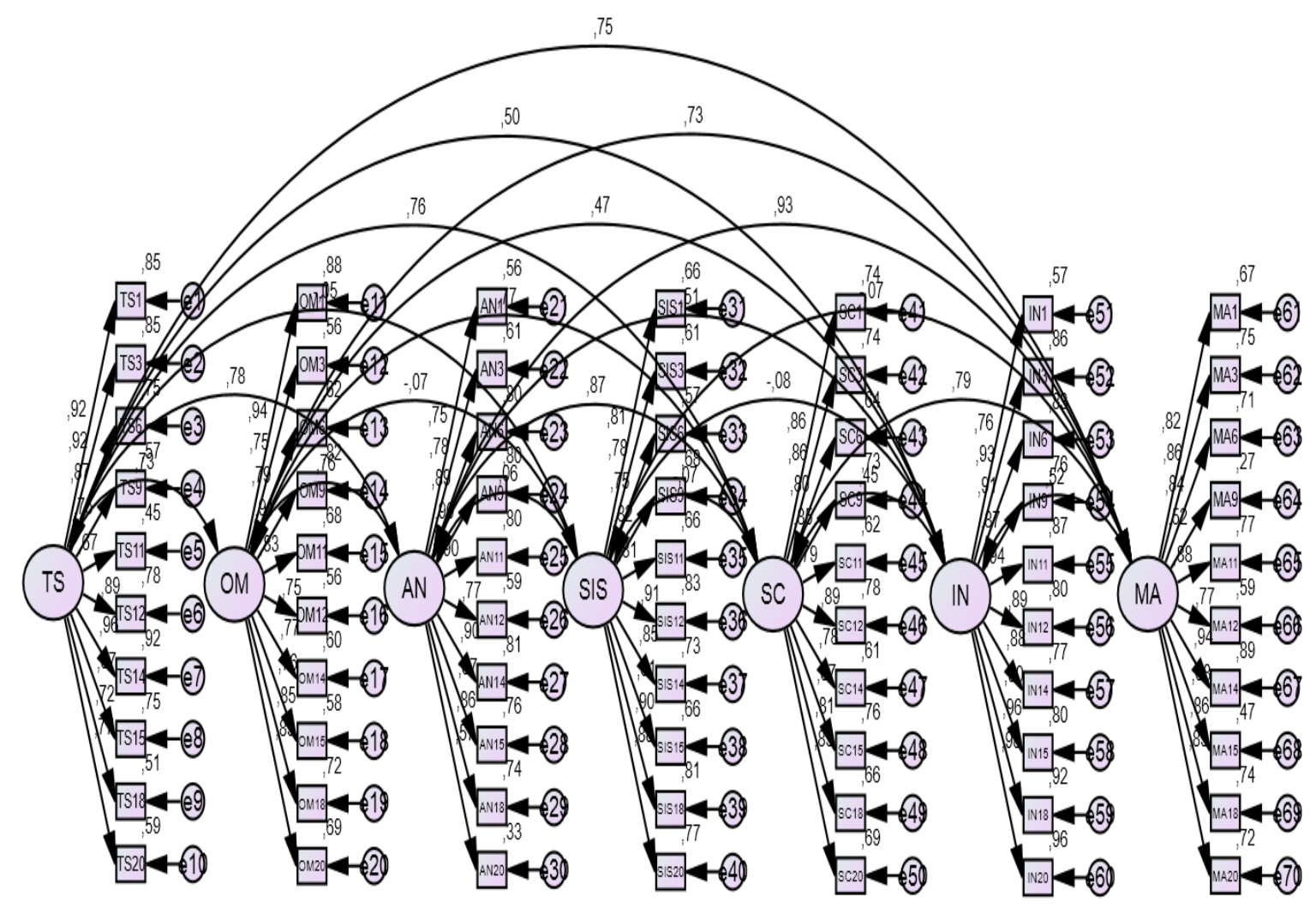

Figure 1.Critical Thinking Disposition Test Model which has confirmed by CFA

The Figure 1 is output of AMOS analysis on CTDTB model. On the picture, it is seen that in every questions represents critical thinking disposition indicator, namely Truth Seeking (TS), Open Mind (OM), Analicity (AN), Sistematicity (SIS),
Self-Confidence (SC), Inquisitiveness (IN) and Maturity (MA) have loading factor score more than 0.5. In detail, loading factor score of 10 questions, that represent seven critical thinking disposition indicators, can be seen in Table 2 .

Table 2. Factor Loading and Convergent Validity

\begin{tabular}{|c|c|c|c|c|c|c|c|c|c|}
\hline \multirow[t]{2}{*}{ Number } & \multirow{2}{*}{\multicolumn{2}{|c|}{$\begin{array}{c}\text { Convergent } \\
\text { validity }\end{array}$}} & \multicolumn{7}{|c|}{ Constructs } \\
\hline & & & $\begin{array}{c}\text { Truth } \\
\text { seeking }\end{array}$ & $\begin{array}{l}\text { Open } \\
\text { mind }\end{array}$ & Analicity & Sistematicity & $\begin{array}{c}\text { Self } \\
\text { confident }\end{array}$ & $\begin{array}{c}\text { Inquisiti } \\
\text { veness }\end{array}$ & Maturity \\
\hline 1. & $A V E$ & & 0.74 & 0.67 & 0.68 & 0.70 & 0.70 & 0.82 & 0.66 \\
\hline \multirow[t]{6}{*}{2.} & $C R$ & & 0.96 & 0.95 & 0.95 & 0.96 & 0.96 & 0.98 & 0.95 \\
\hline & & 1 & 0.920 & 0.937 & 0.745 & 0.811 & 0.860 & 0.756 & 0.817 \\
\hline & & 2 & 0.925 & 0.747 & 0.780 & 0.779 & 0.860 & 0.929 & 0.865 \\
\hline & & 3 & 0.869 & 0.789 & 0.892 & 0.752 & 0.802 & 0.912 & 0.841 \\
\hline & & 4 & 0.753 & 0.908 & 0.897 & 0.822 & 0.854 & 0.869 & 0.516 \\
\hline & Factor & 5 & 0.672 & 0.826 & 0.896 & 0.815 & 0.786 & 0.935 & 0.88 \\
\hline \multirow[t]{5}{*}{3.} & Loading & 6 & 0.886 & 0.750 & 0.770 & 0.912 & 0.886 & 0.893 & 0.766 \\
\hline & & 7 & 0.961 & 0.772 & 0.902 & 0.853 & 0.783 & 0.879 & 0.942 \\
\hline & & 8 & 0.868 & 0.762 & 0.870 & 0.814 & 0.873 & 0.897 & 0.684 \\
\hline & & 9 & 0.715 & 0.850 & 0.861 & 0.902 & 0.809 & 0.961 & 0.858 \\
\hline & & 10 & 0.768 & 0.832 & 0.572 & 0.877 & 0.828 & 0.979 & 0.849 \\
\hline
\end{tabular}

Research finding shown in Table 2 is Average Extract Variance (AVE) and Composite Reliability (CR) score of the seven critical thinking disposition indicators where it can be said as accepted (fulfill acceptance score of $>0.5$ ). The Average Variance Extract scores sequentially are as follows: truth seeking 0.74 , open mind 0.67, analicity 0.68, sistematicity 0.70 , self confidence 0.70 , inquisitiveness 0.82 , and maturity 0.66 . Whereas for Composite Reliability score shows that all indicators has greater score (more than 0.7) namely, truth seeking 0.96, 
open mind 0.95, analicity 0.95, sistematicity 0.96 , self confidence 0.96, inquisitiveness 0.98 , and maturity 0.95 . Composite Reliability (CR) score can be interpreted as reliability value in which after checked the CR value, it is same with Cronbach Alpha value. This is supported with Bollen and Long (1993) who explained that $C R$ value is other guidance to review the reliability test.

Finding of the research shows that Critical Thinking Disposition Test in Biology (CTDTB) has good convergent validity. This is proven by loading factor acceptance value. This finding is supported the research conducted by J Syahfitri et al. (2019) that all critical thinking disposition indicators has score (more than 0.7) namely, truth-seeking 0.96 , open mind 0.94 , analyticity 0.97 , systematicity 0.96 , self-confidence 0.98, inquisitiveness 0.93, and maturity 0.97 . These findings describe that CTDTB is instrument which has fulfilled good instrument criteria. Later on in Jayanti Syahfitri et al. (2019) research, reveals that CTDTKB developed is a feasible test model and fulfill good instrument criteria. This is shown from Confirmatory Factor Analysis (CFA) analysis result.

\section{Conclusion}

After being confirmed using Confirmatory Factor Analysis (CFA), it shows that Critical Thinking Disposition Test in Biology has construct validity that can be accepted (feasible). The result of construct validity test shows that 10 questions clusters are valid with high Composite Reliability (CR) score. Therefore, it can be concluded that Critical Thinking Disposition Test in Biology (CTDTB) is declared valid in construct; it can be one of the instrument alternative in measuring student's critical thinking disposition in biology context. This result proves that student's critical thinking disposition is not only can be measured by inventory type instrument (the existing previous instrument), nevertheless, it also can use Critical Thinking Disposition Test in Biology (CTDTB). This is characteristic of the renewal of the research conducted. Critical Thinking Disposition Test in Biology (CTDTB) can measure student's critical thinking disposition more objectively compared to using inventory instrument. Critical Thinking Disposition
Test in Biology (CTDTB) has question characteristic based on the cases related with biology. Besides that, Critical Thinking Disposition Test in Biology (CTDTB) consists of seven questions that leads to critical thinking disposition indicator, so that, someone's disposition or critical thinking tendencies can be interpreted in detail and thoroughly. On the contrary, inventory instrument is only general statement in nature and susceptible to be manipulated.

Critical Thinking Disposition Test in Biology (CTDTB) can be used by future researchers in learning process. Aside of that, it can be used to predict how far the student's readiness to think critically (Jayanti Syahfitri, 2019). Not only that, this test is also possible to be used to assist in the new student acceptance test in biology education major. Considering that biology education students are required to think critically, so that it can support their academic achievements and readiness to face 21 st century.

\section{Acknowledgment}

My sincere gratitude is for KEMENRISTEKDIKTI that has given me BPPDN scholarship. Also my gratitude is for Dr. Harry Firman M.Pd, Dr. Sri Redjeki, M.Pd, and Siti Sriyati, M.Si as my advisers. As well as for all of the parties who has participated in this research, especially biology education faculty.

\section{References}

Bok, D. (2009). Our underachieving colleges: A candid look at how much students learn and why they should be learning more (Revised). Retrieved from https://books.google.com

Bollen, K. A., \& Long, J. S. (1993). Testing stuctural equation models. Bury Park: SAGE Publications.

Facione, P. A. (1990). Critical thinking: A statement of expert consensus for purposes of educational assessment and intruction. Retrieved from https://philarchive.org/archive/FA CCTA

Facione, P. A. (2000). The disposition toward critical thinking: Its character, measurement, and relationship to critical thinking 
skill. Informal Logic, 20(1), 61-84. https://doi.org/10.22329/il.v20i1. 2254

Facione, P. A., Giancarlo, C. A., Facione, N. C., \& Gainen, J. (1995). The disposition toward critical thinking. Journal of General Education, 44(1), 1-25. Retrieved from https://www.researchgate.net

Foluso, O. (2014). Critical thinking dispositions of nursing faculty in Southwestern Nigeria. IMPACT: International Journal of Research in Applied, Natural and Social Sciences(IMPACT: IJRANSS), 2(8), 127-134. Retrieved from http://www.impactjournals.us/

Foluso, O., \& Caserina, T. (2014). Assessment of critical thinking dispositions of nursing students in Southwestern Nigeria. IMPACT: International Journal of Research in Applied, Natural and Social Sciences(IMPACT: IJRANSS), 2(3), 716. Retrieved from http://oaji.net/

Fornell, C., \& Larcker, D. F. (1981). Evaluating structural equation models with unobservable variables and measurement error. Journal of Marketing Research, 18(1), 39-50. https://doi.org/10.1177/00222437 8101800104

Furnham, A. (1986). Response bias, social desirability and dissimulation. Personality and Individual Differences, $\quad 7(3), \quad 385-400$. https://doi.org/10.1016/01918869(86)90014-0

Ghadi, I., Alwi, N. H., Bakar, K. A., \& Talib, O. (2012). Construct validity examination of critical thinking dispositions for undergraduate students in University Putra Malaysia. Higher Education Studies, 2(2), 138-144. https://doi.org/ 10.5539/hes.v2n2p138

Hair, J. F. (2011). Multivariate data analysis: An overview. In International Encyclopedia of Statistical Science (pp. 904-907). https://doi.org/ 10.1007/978-3-642-04898-2_395

Hongladarom, S. (2007). Asian philosophy and critical thinking: Divergence or convergence? Retrieved from http://pioneer.chula.ac.th/ hsoraj /web/APPEND.html
Marcus, B. (2009). 'Faking' from the applicant's perspective: A theory of self-presentation in personnel selection settings. International Journal of Selection and Assessment, 17(4), 417-430. https://doi.org/10.1111/j.14682389.2009.00483.x

Nederhof, A. J. (1985). Methods of coping with social desirability bias: A review. European Journal of Social Psychology, 15(3), 263-280. https://doi.org/10.1002/ejsp.2420 150303

Nieto, A. M., \& Valenzuela, J. (2012). A study of the internal structure of critical thinking dispositions. Inquiry: Critical Thinking Across the Disciplines, 27(1), 31-38. https://doi.org/10.5840/inquiryct 20122713

Syahfitri, J, Firman, H., Redjeki, S., \& Sriyati, S. (2019). Confirmatory factor analysis of critical thinking disposition test in university biology. Journal of Physics: Conference Series, 1280(3), 1-6. https://doi.org/10.1088/17426596/1280/3/032001

Syahfitri, Jayanti. (2019). Pengujian validitas dan praktikalitas tes disposisi berpikir kritis dalam biologi (TDBKB). JURNAL PENDIDIKAN SAINS (JPS), 7(1), 3035. https://doi.org/10.26714/jps.7. 1.2019.30-35

Syahfitri, Jayanti, Firman, H., Redjeki, S., \& Sriyati, S. (2019). Development and validation of critical thinking disposition test in biology. International Journal of Instruction, 12(4), 381-392. https://doi.org/10. 29333/iji.2019.12425a

Widarjono, A. (2015). Analisis multivariat terapan. Yogyakarta: UPP STIM YKPN.

Widhiarso, W. (2010). Kecenderungan subjek memberikan respon menipu terhadap skala psikologi. Yogyakarta: Universitas Gajah Mada.

Widhiarso, W. (2011). Orientasi kepatutan sosial dan respons tipuan pada alat ukur dalam konteks seleksi kerja. BENEFIT Jurnal Manajemen Dan Bisnis, 15(2), 79-90. Retrieved from https://publikasiilmiah.ums.ac.id/ 